Article

\title{
New Mononuclear Mn(III) Complexes with Hydroxyl-Substituted Hexadentate Schiff Base Ligands
}

\author{
Peng-Yu Xu (D), Yu-Ting Wang (D), Zong-Mei Yu (D), Yong-Hua Li (D) and Shi Wang *(D) \\ Jiangsu National Synergistic Innovation Center for Advanced Materials (SICAM), Key Laboratory for Organic \\ Electronics and Information Displays \& Institute of Advanced Materials (IAM), Nanjing University of Posts \& \\ Telecommunications, Nanjing 210023, China; 1019061510@njupt.edu.cn (P.-Y.X.); \\ 1219064317@njupt.edu.cn (Y.-T.W.); $1019061413 @$ njupt.edu.cn (Z.-M.Y.); iamyhli@njupt.edu.cn (Y.-H.L.) \\ * Correspondence: iamswang@njupt.edu.cn; Tel.: +86-25-8586-6396
}

check for

updates

Citation: Xu, P.-Y.; Wang, Y.-T.; Yu, Z.-M.; Li, Y.-H.; Wang, S. New Mononuclear Mn(III) Complexes with Hydroxyl-Substituted Hexadentate Schiff Base Ligands. Magnetochemistry 2021, 7, 12. https://doi.org/10.3390/ magnetochemistry7010012

Received: 10 December 2020 Accepted: 11 January 2021 Published: 13 January 2021

Publisher's Note: MDPI stays neutral with regard to jurisdictional clai$\mathrm{ms}$ in published maps and institutional affiliations.

Copyright: $\odot 2021$ by the authors. Licensee MDPI, Basel, Switzerland. This article is an open access article distributed under the terms and conditions of the Creative Commons Attribution (CC BY) license (https:// creativecommons.org/licenses/by/ $4.0 /)$.

\begin{abstract}
This paper reports the syntheses, crystal structures and magnetic properties of Mn(III) hexadentate Schiff base complexes [Mn(4-OH-sal-N-1,5,8,12)] $\mathrm{NO}_{3}(\mathbf{1})$ and $[\mathrm{Mn}(4-\mathrm{OH}-\mathrm{sal}-\mathrm{N}-1,5,8,12)] \mathrm{ClO}_{4}$ (2), where (4-OH-sal-N-1,5,8,12) ${ }^{2-}\left(4,4^{\prime}-((1 \mathrm{E}, 13 \mathrm{E})-2,6,9,13-\right.$ tetraazatetradeca-1,13-diene-1,14-diyl)bis(3methoxyphenol) is a new hydroxyl-substituted hexadentate Schiff base ligand. The introduction of the (4-OH-sal-N-1,5,8,12) ${ }^{2-}$ ligand induces more hydrogen bonding interactions, in addition to promoting the formation of intermolecular interactions among the cations. However, the close-packing structures of both complexes lead to their stabilization in the high-spin state in the temperature range of $2-300 \mathrm{~K}$.
\end{abstract}

Keywords: spin crossover; manganese(III); hydrogen bonding; crystal structure

\section{Introduction}

Spin crossover (SCO), which is a hot topic in modern materials science [1-6], occurs in octahedral transition metal complexes with electron configurations of $3 d^{4}-3 d^{7}$. The phenomenon between a low-spin (LS) and a high-spin (HS) state may be triggered by the use of external stimuli, such as light, heat, magnetic field, and pressure [7-11].

Schiff bases are used widely because they are readily derivatized and generally easy to prepare. As versatile ligands, they can stabilize a wide range of geometries and oxidation states in transition metal complexes. This great diversity may permit the design of Schiff bases with a suitable ligand field strength to obtain Mn(III) SCO complexes. Notably, the first $\mathrm{SCO} \mathrm{d}^{4}$ system [Mn(pyrol) ${ }_{3}$ tren] with a hexadentate $\mathrm{N}_{6}$ Schiff base ligand was designed in 1981 by Sinn and Sim [12], breaking the conventional wisdom that it was too difficult to generate an amenable ligand-field strength to stabilize an LS state in $\mathrm{Mn}$ (III) complexes. Later, the prototypic gradual SCO phenomenon of a $\mathrm{Mn}$ (III) hexadentate $\mathrm{N}_{4} \mathrm{O}_{2}$ Schiff base complex was reported in 2006 by Morgan et al. [13] Subsequently, another ligand system, a tridentate Schiff base $\mathrm{N}_{2} \mathrm{O}$ ligand provided the third example of $\mathrm{Mn}(\mathrm{III})$ SCO compounds [14].

$\mathrm{Mn}(\mathrm{III})$ hexadentate Schiff base compounds with $\mathrm{N}_{4} \mathrm{O}_{2}$ donor sets are extensively studied [13,15-30] from various aspects such as ligand substitution [31], the nature of counter anions [32-34], and the cocrystallized solvent molecules [35-38]. The chemical influences affect intermolecular interactions like crystal packing and hydrogen bonding, which offer more possibilities for cooperative SCO behaviors. In previous reports, we reported a series of $\mathrm{Mn}(\mathrm{III})$ hexadentate Schiff base compounds [Mn(sal-N-1,5,8,12)]Y $\left(\mathrm{Y}=\mathrm{Cl}^{-}, \mathrm{PF}_{6}{ }^{-}, \mathrm{AsF}_{6}{ }^{-}, \mathrm{SbF}_{6}{ }^{-}\right.$, and $\left.\mathrm{NO}_{3}{ }^{-}\right)$[25] to confirm that the counter anion effects are clearly related to the SCO behavior. Moreover, cocrystallized solvent molecules affect the SCO profoundly. For instance, the complexes $\left[\mathrm{Mn}(3,5-\mathrm{diBr}\right.$-sal-N-1,5,8,12) $] \mathrm{ClO}_{4} \cdot \mathrm{C}_{2} \mathrm{H}_{5} \mathrm{OH}$ and $[\mathrm{Mn}(3,5-\mathrm{diBr}-\mathrm{sal}-\mathrm{N}-1,5,8,12)] \mathrm{ClO}_{4} \cdot 0.5 \mathrm{CH}_{3} \mathrm{CN}$ show different $\mathrm{SCO}$ behaviors [19]. The ethanol solvate has a more complete SCO while the latter persists in the LS state 
over a considerable temperature range. Besides, the analysis of $\mathrm{Mn}(\mathrm{III})$ complexes with various hexadentate Schiff base ligands, such as (3-OMe-sal-N-1,5,8,12) ${ }^{2-}$ [22], (5-OMesal-N-1,5,8,12) ${ }^{2-}[24,30],(5-B r-s a l-N-1,5,8,12)^{2-}$ [18] and (naphth-sal-N-1,5,8,12) ${ }^{2-}$ [29], has emphasized the impact of the substituent effects.

In addition, the report on the 4-position of salicylaldehyde of hexadentate Schiff base ligands is rare; however, a series of $\mathrm{Mn}(\mathrm{III}) \mathrm{SCO}$ compounds [Mn(4-R-sal-N-1,5,8,12)]Y $\left(\mathrm{R}=\mathrm{OC}_{6} \mathrm{H}_{13}, \mathrm{OC}_{12} \mathrm{H}_{25}, \mathrm{OC}_{18} \mathrm{H}_{37}\right.$ ) with gradual and uncompleted SCO behavior were reported by Albrecht and his co-workers [16]. Under this circumstance, we study to obtain complexes that can provide strong cooperation interactions and more complete SCO behaviors. Therefore, the complexes [Mn(4-OH-sal- N-1,5,8,12)]Y $\left(\mathrm{Y}^{-}=\mathrm{NO}_{3}{ }^{-}\right.$and $\left.\mathrm{ClO}_{4}{ }^{-}\right)$ (Scheme 1) were selected with the following main goals: increase the number of hydrogen bonds through the hydroxyl group, in order to strengthen the connection between anions and cations and improve the cooperativity of the system.

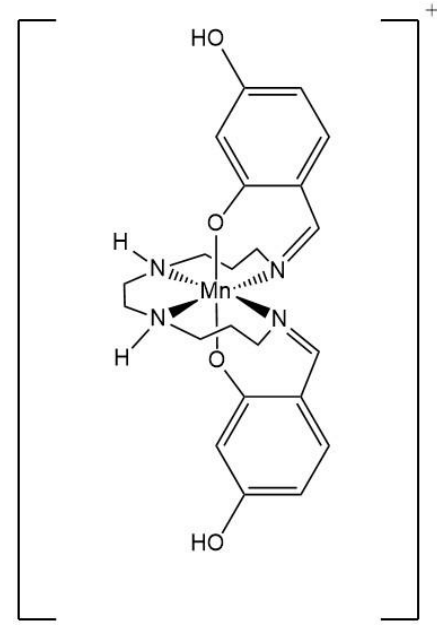

Scheme 1. Structural unit of the cation $[\mathrm{Mn}(4-\mathrm{OH}-\mathrm{sal}-\mathrm{N}-1,5,8,12)]^{+}$.

Herein, we report the synthesis, $\mathrm{X}$-ray crystal structures, and magnetic properties of two isostructural compounds with the general formula [Mn(4-OH-sal-N-1,5,8,12)]Y $\left(\mathrm{Y}=\mathrm{NO}_{3}{ }^{-}\right.$and $\left.\mathrm{ClO}_{4}{ }^{-}\right)$. Correlations between properties and structures are discussed with respect to the alteration of the geometry and hydrogen-bonding acceptor of the anions.

\section{Experimental Section}

All of the reagents and chemicals were analytically pure, purchased from commercial sources, and were used without further purification. Although we experienced no problems with the compounds reported in this work, the manganese perchlorate salt with the organic ligand is potentially explosive and should be handled with great care and used in small amounts. Elemental analyses of C, H, and N were performed on a Vario EL III elemental analyzer. IR spectra of the solid samples (KBr tablets) in the range $400-4000 \mathrm{~cm}^{-1}$ were recorded by an FT-IR Perkin Elmer spectrometer. The properties of the Hirshfeld surface for complexes 1 and 2 were generated using a CrystalExplorer 17.5. The Hirshfeld surface was generated using a high resolution and mapped with the $\mathrm{d}_{\text {norm }}$ and shape-indexed functions. 2D fingerprint plots were prepared using the same software. Magnetic susceptibility was measured in a sweep mode upon cooling from 300 to $2 \mathrm{~K}$ under a $0.1 \mathrm{~T}$ applied magnetic field by the use of a Quantum Design MPMS SQUID VSM magnetometer. A freshly prepared crystalline sample was placed in a gelatin capsule holder. Magnetic data were calibrated with the sample holder and diamagnetic corrections were estimated from Pascal's constants. Magnetic behavior was primarily analyzed by using variable-temperature magnetic susceptibility measurements.

[Mn(4-OH-sal-N-1,5,8,12) $\mathrm{NO}_{3}$ (1) 2,4-dihydroxybenzaldehyde (31.4 mg, $\left.0.228 \mathrm{mmol}\right)$ and N,N-bis(3-aminopropyl)ethylenediamine (21.4 $\mathrm{mg}, 0.114 \mathrm{mmol})$ dissolved in methanol 
$(6 \mathrm{~mL})$, and then solid manganese(II) nitrate tetrahydrate $(33.4 \mathrm{mg}, 0.114 \mathrm{mmol})$ was added. The resulting dark brown solution was stirred for half an hour and then filtered. Black crystals formed upon evaporation of the solvent (56.9\%). Anal. calcd for $\mathrm{C}_{22} \mathrm{H}_{28} \mathrm{MnN}_{5} \mathrm{O}_{7}$ : C, 49.91; H, 5.33; N, 13.23. Found: C, 49.86; H, 5.35; N, 13.16. IR (cm $\left.{ }^{-1}\right): 3550$ (m, sh), 1613 (m, sh), 1338 (m, sh).

[Mn(4-OH-sal-N-1,5,8,12) $\mathrm{ClO}_{4}$ (2) 2,4-dihydroxybenzaldehyde (45.8 mg, $0.332 \mathrm{mmol}$ ) and N,N-bis(3-aminopropyl)ethylenediamine $(28.9 \mathrm{mg}, 0.166 \mathrm{mmol})$ dissolved in methanol (6 mL), and then solid manganese(II) perchlorate hexahydrate (41.9 $\mathrm{mg}, 0.166 \mathrm{mmol})$ was added. The resulting dark brown solution was stirred for half an hour and then filtered. Black crystals formed upon evaporation of the solvent $(63.8 \%)$. Anal. calcd for $\mathrm{C}_{22} \mathrm{H}_{28} \mathrm{ClMnN}_{4} \mathrm{O}_{8}: \mathrm{C}, 46.61 ; \mathrm{H}, 4.98 ; \mathrm{N}, 9.88$. Found: $\mathrm{C}, 46.66 ; \mathrm{H}, 4.94 ; \mathrm{N}, 9.83$. IR $\left(\mathrm{cm}^{-1}\right)$ : 3552 (m, sh), 1618 (m, sh), 1076 (st,sh), 619 (m, b).

\section{Results and Discussion}

\subsection{Crystallographic Studies}

Single-crystal X-ray diffraction data for the compounds [Mn(4-OH-sal-N-1,5,8,12)] $\mathrm{NO}_{3}$ (1) and $\left[\mathrm{Mn}\left(4-\mathrm{OH}-\right.\right.$ sal-N-1,5,8,12) $\mathrm{ClO}_{4}$ (2) were collected at 100 and $298 \mathrm{~K}$, respectively. Table 1 presents the most relevant parameters for single-crystal determination.

Table 1. Selected crystallographic data for complexes $\mathbf{1}$ and $\mathbf{2 .}$

\begin{tabular}{|c|c|c|c|c|}
\hline \multirow{2}{*}{ Formula } & \multicolumn{2}{|c|}{1} & \multicolumn{2}{|c|}{2} \\
\hline & \multicolumn{2}{|c|}{$\mathrm{C}_{22} \mathrm{H}_{28} \mathrm{MnN}_{5} \mathrm{O}_{7}$} & \multicolumn{2}{|c|}{$\mathrm{C}_{22} \mathrm{H}_{28} \mathrm{ClMnN}_{4} \mathrm{O}_{8}$} \\
\hline CCDC & $2,043,724$ & $2,043,725$ & $2,043,722$ & $2,043,723$ \\
\hline$T, \mathbf{K}$ & $100 \mathrm{~K}$ & $298 \mathrm{~K}$ & $100 \mathrm{~K}$ & $298 \mathrm{~K}$ \\
\hline Crystal system & triclinic & triclinic & triclinic & triclinic \\
\hline Space group & $P \overline{1}$ & $P \overline{1}$ & $P \overline{1}$ & $P \overline{1}$ \\
\hline$Z$ & 2 & 2 & 2 & 2 \\
\hline$a, \AA$ & 9.4195(19) & $9.4904(10)$ & $9.6692(14)$ & $9.883(7)$ \\
\hline$b, \AA$ & $10.455(2)$ & $10.4832(10)$ & $10.5597(15)$ & $10.741(7)$ \\
\hline$c, \AA$ & $12.733(3)$ & $12.8865(13)$ & $12.8271(18)$ & $13.204(10)$ \\
\hline$\alpha, \operatorname{deg}$ & $93.434(5)$ & $93.556(2)$ & $93.505(3)$ & $94.021(15)$ \\
\hline$\beta, \operatorname{deg}$ & $106.356(4)$ & $106.793(2)$ & 107.134(3) & $108.463(17)$ \\
\hline$\gamma, \operatorname{deg}$ & $107.143(5)$ & $106.914(2)$ & $105.371(3)$ & $104.578(16)$ \\
\hline$V, \AA^{3}$ & $1135.7(4)$ & $1159.3(2)$ & 1192.9(3) & $1269.4(15)$ \\
\hline$D_{\text {calc }}, \mathrm{g} \mathrm{cm}^{-3}$ & 1.548 & 1.517 & 1.578 & 1.483 \\
\hline$\mu, \mathrm{mm}^{-1}$ & 0.637 & 0.624 & 0.722 & 0.679 \\
\hline $\mathrm{F}(000)$ & 552 & 552 & 588 & 588 \\
\hline \multirow[t]{3}{*}{$h k l$ range } & $-11 \leq h \leq 11$ & $-8 \leq h \leq 11$ & $-12 \leq h \leq 10$ & $-11 \leq h \leq 9$ \\
\hline & $-8 \leq k \leq 12$ & $-12 \leq k \leq 11$ & $-14 \leq k \leq 13$ & $-12 \leq k \leq 12$ \\
\hline & $-15 \leq l \leq 15$ & $-15 \leq l \leq 15$ & $-16 \leq l \leq 17$ & $-14 \leq l \leq 15$ \\
\hline Collected & 7306 & 7846 & 10719 & 7399 \\
\hline Parameters & 333 & 333 & 336 & 339 \\
\hline Goodness-of-fit & 1.033 & 1.075 & 1.022 & 1.081 \\
\hline $\mathrm{R}_{1}[\mathrm{I}>2 \sigma(\mathrm{I})]$ & 0.0525 & 0.0310 & 0.0291 & 0.1847 \\
\hline $\mathrm{wR}_{2}[\mathrm{I}>2 \sigma(\mathrm{I})]$ & 0.1328 & 0.0917 & 0.0722 & 0.0614 \\
\hline $\max . / \min .\left[\mathrm{e} \AA^{-3}\right]$ & $0.99 /-0.91$ & $0.63 /-0.51$ & $0.38 /-0.44$ & $0.56 /-0.91$ \\
\hline
\end{tabular}

At both temperatures (100 and $298 \mathrm{~K}$ ), the two isomorphic complexes crystallized in the triclinic $P \overline{1}$ space group. The asymmetric unit of 1 contained one [Mn(4-OH-sal$\mathrm{N}-1,5,8,12)]^{+}$cation and one $\mathrm{NO}_{3}{ }^{-}$counter anion (Figure 1 ), while one [Mn(4-OH-sal$\mathrm{N}-1,5,8,12)]^{+}$cation and one $\mathrm{ClO}_{4}{ }^{-}$anion were observed in the structure of 2 (Figure 2). In these compounds, the $\mathrm{Mn}^{3+}$ ion was coordinated pseudo-octahedrally by trans-O (O1 and $\mathrm{O} 2$ ) donors in the axial position and pairs of cis-imine (N1 and N4) and cis-amine (N2 and N3) in the equatorial plane. The Mn- $\mathrm{N}_{\text {imine }}\left(\mathrm{N} 1\right.$ and N4) (2.075-2.135 $\AA$ ), $\mathrm{Mn}-\mathrm{N}_{\text {amine }}$ (N2 and N3) (2.233-2.291 $\AA$ ), and Mn-O (1.864-1.880 $\AA$ ) bond lengths at $100 \mathrm{~K}$ were in greatagreement with those observed in other HS Mn(III) hexadentate Schiff base complexes. 
Moreover, the bond lengths of the complexes at $298 \mathrm{~K}$ had no significant change compared with those at $100 \mathrm{~K}$ (Table 2).
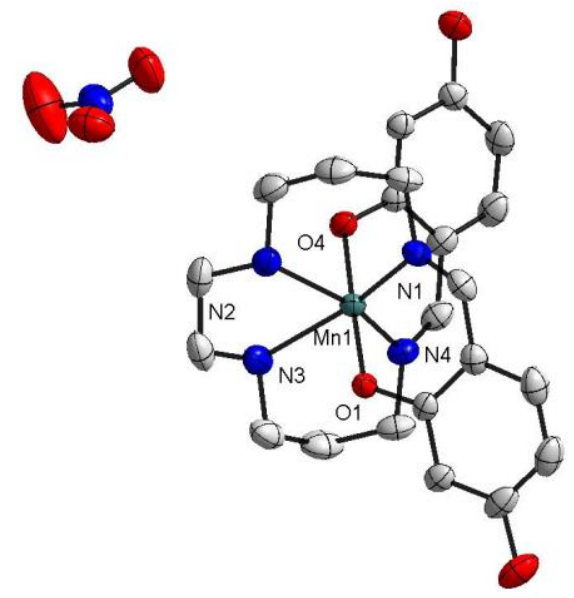

Figure 1. The structure of $[\mathrm{Mn}(4-\mathrm{OH}-\mathrm{sal}-\mathrm{N}-1,5,8,12)] \mathrm{NO}_{3}$ at $T=100 \mathrm{~K}$. Ellipsoids are drawn at the $50 \%$ probability level. Hydrogen atoms were omitted for clarity.

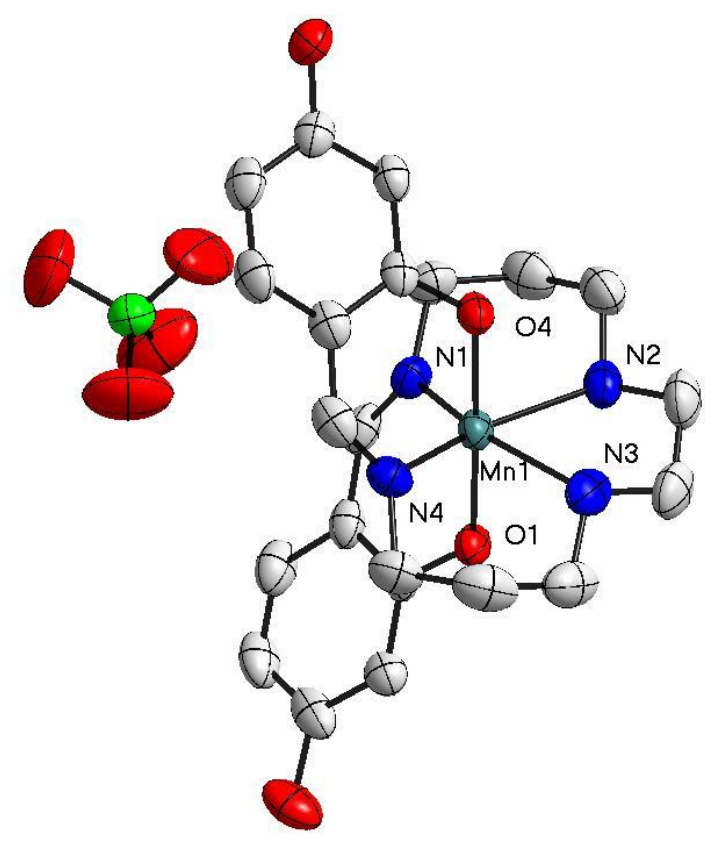

Figure 2. The structure of $[\mathrm{Mn}(4-\mathrm{OH}-\mathrm{sal}-\mathrm{N}-1,5,8,12)] \mathrm{ClO}_{4}$ at $T=100 \mathrm{~K}$. Ellipsoids are drawn at the $50 \%$ probability level. Hydrogen atoms were omitted for clarity.

The octahedral distortion parameters $\Sigma$ and $\theta$ can intuitively reflect the changes of the $\mathrm{Mn}$ (III) coordination sphere. For complex $1, \theta$ was from $292.38^{\circ}$ at $100 \mathrm{~K}$ to $291.98^{\circ}$ at $298 \mathrm{~K}$, while the change in $\Sigma$ was small, with values of $79.59^{\circ}$ and $79.41^{\circ}$, respectively. Both parameters, with a little change, further demonstrate that there was no SCO behavior in complex $\mathbf{1}$. The central $\mathrm{Mn}^{3+}$ ion of compound 2, which is similar to complex $\mathbf{1}$, was furnishing a distorted octahedral geometry $\left(\theta=289.93^{\circ}\right.$ and $\Sigma=77.66^{\circ}$ at $100 \mathrm{~K} ; \theta=294.06^{\circ}$ and $\Sigma=78.90^{\circ}$ at $298 \mathrm{~K}$ ). 
Table 2. Selected bond distances $(\AA)$, angles $\left(^{\circ}\right)$, and octahedral distortion parameters $\left(^{\circ}\right)$ for complexes 1 and 2.

\begin{tabular}{|c|c|c|c|c|}
\hline \multirow[b]{2}{*}{$T, \mathrm{~K}$} & \multicolumn{2}{|c|}{1} & \multicolumn{2}{|c|}{2} \\
\hline & $100 \mathrm{~K}$ & $298 \mathrm{~K}$ & $100 \mathrm{~K}$ & $298 \mathrm{~K}$ \\
\hline \multicolumn{5}{|c|}{ Bond distances } \\
\hline Mn1-N1 & $2.121(3)$ & $2.1194(16)$ & $2.0839(13)$ & $2.148(3)$ \\
\hline Mn1-N2 & $2.233(3)$ & $2.2375(17)$ & $2.2912(13)$ & $2.267(3)$ \\
\hline Mn1-N3 & $2.273(3)$ & $2.2747(18)$ & $2.2369(13)$ & $2.310(3)$ \\
\hline Mn1-N4 & $2.075(3)$ & $2.0852(16)$ & $2.1346(13)$ & $2.116(3)$ \\
\hline Mn1-Nav & 2.1755 & 2.1792 & 2.18665 & 2.210 \\
\hline Mn1-O1 & $1.864(2)$ & $1.8688(12)$ & $1.8797(11)$ & $1.894(3)$ \\
\hline Mn1-O4 & $1.872(2)$ & $1.8748(13)$ & $1.8742(11)$ & $1.903(3)$ \\
\hline Mn1-Oav & 1.868 & 1.8718 & 1.87695 & 1.8985 \\
\hline \multicolumn{5}{|c|}{ Bond angles } \\
\hline O4-Mn1-N1 & $92.22(10)$ & $92.31(6)$ & $91.53(5)$ & $91.79(13)$ \\
\hline O1-Mn1-N1 & $86.86(10)$ & $86.84(6)$ & $88.35(5)$ & $86.85(13)$ \\
\hline O4-Mn1-N4 & $87.88(10)$ & $87.91(6)$ & $86.93(5)$ & 88.51(13) \\
\hline O1-Mn1-N4 & $91.43(10)$ & $91.29(6)$ & $91.42(5)$ & $91.17(13)$ \\
\hline N1-Mn1-N4 & $116.80(10)$ & $116.81(6)$ & $116.38(5)$ & $116.84(13)$ \\
\hline O4-Mn1-N3 & $95.42(10)$ & $94.46(6)$ & $93.77(5)$ & 96.33(13) \\
\hline O1-Mn1-N3 & $85.86(9)$ & $85.79(6)$ & $86.95(5)$ & $85.30(13)$ \\
\hline N4-Mn1-N3 & $83.15(10)$ & $83.17(7)$ & $82.65(5)$ & $83.18(15)$ \\
\hline O4-Mn1-N2 & $86.35(10)$ & $86.53(6)$ & $85.33(5)$ & $86.68(12)$ \\
\hline O1-Mn1-N2 & $94.76(10)$ & $94.67(6)$ & $96.54(5)$ & $94.16(13)$ \\
\hline N1-Mn1-N2 & $82.87(10)$ & $82.88(7)$ & $83.60(5)$ & $82.33(13)$ \\
\hline N3-Mn1-N2 & $78.07(10)$ & 78.01(7) & 78.18(5) & $78.48(15)$ \\
\hline O4-Mn1-O1 & $178.46(9)$ & $178.42(5)$ & $178.10(4)$ & $178.29(10)$ \\
\hline N1-Mn1-N3 & 158.93(10) & $158.85(7)$ & $160.52(5)$ & $158.64(14)$ \\
\hline N4-Mn1-N2 & 159.72(10) & 159.75(7) & 158.77(5) & $160.39(13)$ \\
\hline \multicolumn{5}{|c|}{ Mn-Mn distance } \\
\hline interchain & $6.709(1)$ & $6.749(6)$ & $6.740(8)$ & $6.841(4)$ \\
\hline intrachain & $8.337(1)$ & $8.349(7)$ & $8.335(9)$ & $8.431(4)$ \\
\hline \multicolumn{5}{|c|}{ Octahedral distortion parameters } \\
\hline$\theta$ & 292.38 & 291.98 & 289.93 & 294.06 \\
\hline$\Sigma$ & 79.59 & 79.41 & 77.66 & 78.90 \\
\hline
\end{tabular}

In Figure 3, a pair of [Mn(4-OH-sal-N-1,5,8,12) $]^{+}$cations form a centrosymmetric dimer through the $\mathrm{N}-\mathrm{H} \cdots \mathrm{O}$ hydrogen bonds between the amino nitrogen atoms and peripheral hydroxy oxygen atoms. Moreover, weak edge-to-edge $\pi \cdots \pi$ contacts exist between the two sets of $C(1)-C(2)$ atoms (Figure 4), and stabilize the dimer structure.

The anions connected cationic dimers located in chains via the $\mathrm{O}-\mathrm{H} \cdots \mathrm{O}$ hydrogen bonds (Figure 3). The supramolecular chains were relatively independent and extended infinitely in the $b c$-plane. With the increase of the temperature, there was no significant change in the strength of the hydrogen bonds (Table 3). The intrachain Mn-Mn separation was $8.337 \AA$ at $100 \mathrm{~K}$ and $8.349 \AA$ at $298 \mathrm{~K}$. However, the formation of dimers resulted in the short interchain Mn $\cdots$ Mn distance, which was $6.709 \AA$ at $100 \mathrm{~K}$ and $6.749 \AA$ at $298 \mathrm{~K}$, respectively. The close $\mathrm{Mn}-\mathrm{Mn}$ distance gave the $[\mathrm{Mn}(4-\mathrm{OH}-\mathrm{sal}-\mathrm{N}-1,5,8,12)]^{+}$cation less space to change the coordination geometry.

As for complex 2, increasing the size of the anion from planar $\mathrm{NO}_{3}{ }^{-}$to tetrahedral $\mathrm{ClO}_{4}{ }^{-}$resulted in more intricate interconnections, but there was no change in crystal packing. Moreover, the formations of supramolecular dimers indicate the close contacts between the $[\mathrm{Mn}(4-\mathrm{OH}-\mathrm{sal}-\mathrm{N}-1,5,8,12)]^{+}$cations. The existence of $\mathrm{O}(2)-\mathrm{H}(2) \cdots \mathrm{O}(7), \mathrm{O}(7)-$ $\mathrm{H}(27) \cdots \mathrm{O}(3)$ and $\mathrm{O}(6)-\mathrm{H}(27) \cdots \mathrm{O}(3)$ hydrogen bonds contributed to the close stacking between the anions and cations, which hindered the flexibility of the whole ligand and 
prevented the distortion of the Mn(III) coordination geometry (Figure 5). In addition, the interchain Mn-Mn separation changed from 6.841 at $298 \mathrm{~K}$ to $6.740 \AA$ at $100 \mathrm{~K}$ because of its bigger anion size. However, this did not give the $\mathrm{Mn}(\mathrm{III})$ cation enough space to change its conformation to meet the structural requirements of SCO.

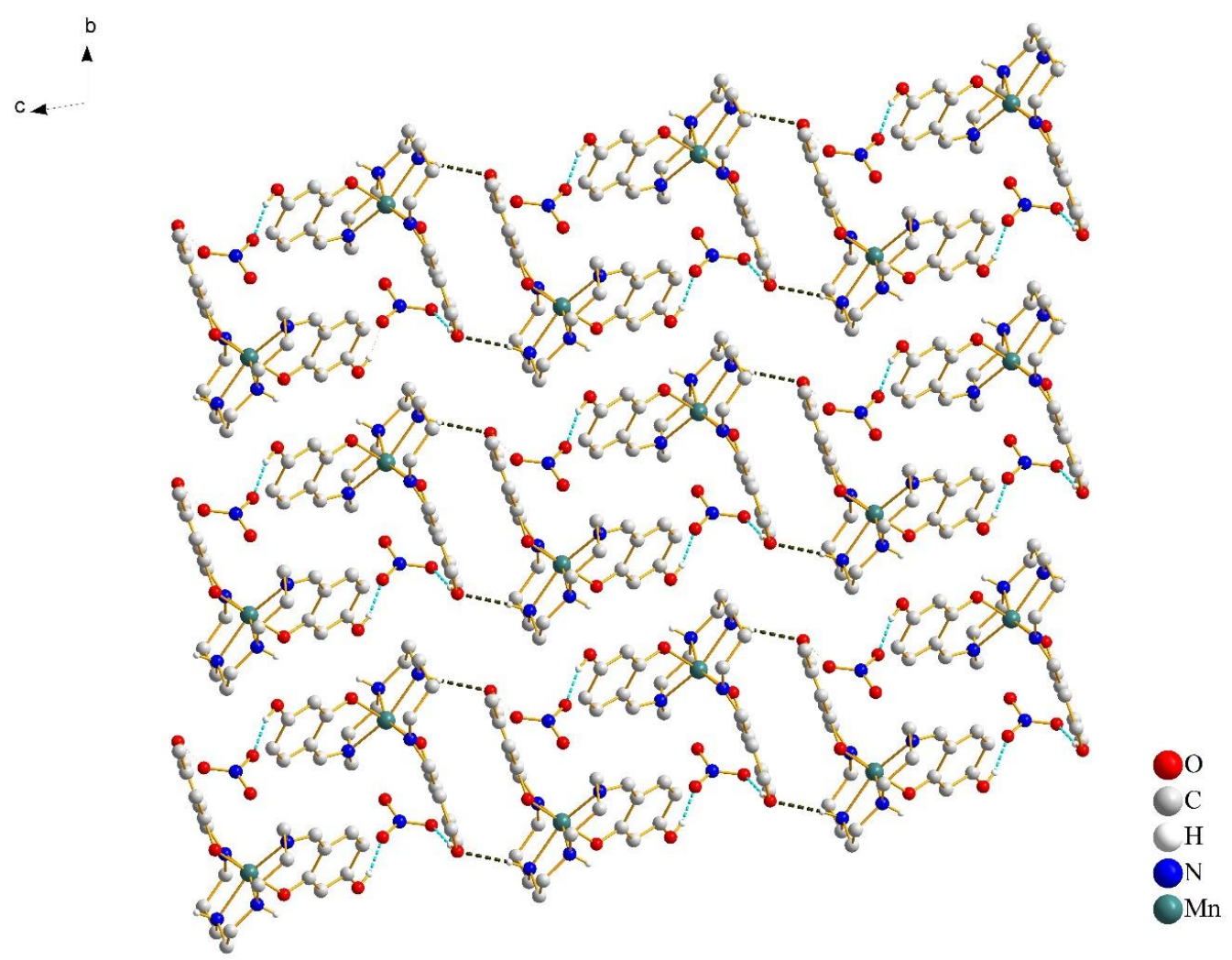

Figure 3. Crystal packing of complex $\mathbf{1}$ at $100 \mathrm{~K}$, viewed along the $a$-axis. The cation-anion $\mathrm{O}-\mathrm{H} \cdots \mathrm{O}$ hydrogen bonds are shown with cyan blue dash lines and the cation-cation $\mathrm{N}-\mathrm{H} \cdots \mathrm{O}$ hydrogen bonds are shown with black lines. Most of the hydrogen atoms were omitted for clarity, except for those involved in hydrogen bonds.

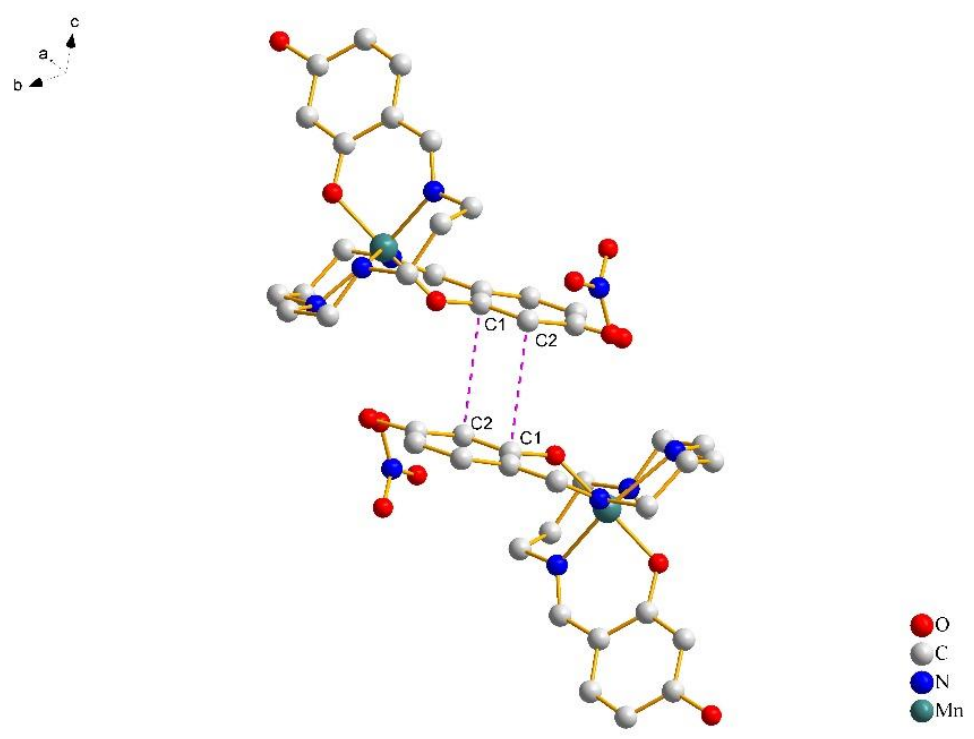

Figure 4. The details of $\pi \cdots \pi$ stacking interactions between phenolate rings of complex 1 at $100 \mathrm{~K}$. Hydrogen atoms were omitted for clarity. 
Table 3. Hydrogen bond distances and parameters for the complexes of $\mathbf{1}$ and $\mathbf{2}\left(\AA,^{\circ}\right)$.

\begin{tabular}{|c|c|c|c|c|c|c|c|c|c|}
\hline \multicolumn{10}{|c|}{1} \\
\hline \multicolumn{5}{|c|}{$100 \mathrm{~K}$} & \multicolumn{5}{|c|}{$298 \mathrm{~K}$} \\
\hline $\mathrm{D}-\mathrm{H} \cdots \mathrm{A}$ & D-H & $\mathrm{H} \cdots \mathrm{A}$ & $\mathrm{D} \cdots \mathrm{A}$ & angle & $\mathrm{D}-\mathrm{H} \cdots \mathrm{A}$ & D-H & $\mathrm{H} \cdots \mathrm{A}$ & $\mathrm{D} \cdots \mathrm{A}$ & angle \\
\hline $\mathrm{N} 2-\mathrm{H} 12 \cdots \mathrm{O} 2^{\mathrm{i}}$ & $0.78(5)$ & $2.32(5)$ & $3.091(4)$ & $170(4)$ & $\mathrm{N} 2-\mathrm{H} 12 \cdots \mathrm{O} 2$ iv & $0.87(2)$ & $2.25(3)$ & $3.108(3)$ & $171(2)$ \\
\hline $\mathrm{O} 2-\mathrm{H} 2 \cdots \mathrm{O} 7{ }^{\mathrm{ii}}$ & $0.72(5)$ & $1.96(5)$ & $2.677(4)$ & $175(4)$ & $\mathrm{O} 2-\mathrm{H} 2 \cdots \mathrm{O} 5^{v}$ & $0.71(4)$ & $2.01(4)$ & $2.711(3)$ & 177(3) \\
\hline $\mathrm{O} 3-\mathrm{H} 27 \cdots \mathrm{O}^{\mathrm{iii}}$ & $0.80(4)$ & $2.04(5)$ & $2.796(4)$ & $158(4)$ & $\mathrm{O} 3-\mathrm{H} 27 \cdots \mathrm{O}^{\mathrm{vi}}$ & $0.79(3)$ & $2.06(3)$ & $2.807(3)$ & $158(3)$ \\
\hline \multicolumn{10}{|c|}{2} \\
\hline \multicolumn{5}{|c|}{$100 \mathrm{~K}$} & \multicolumn{5}{|c|}{$298 \mathrm{~K}$} \\
\hline D-H $\cdots A$ & D-H & $\mathrm{H} \cdots \mathrm{A}$ & $\mathrm{D} \cdots \mathrm{A}$ & angle & D-H $\cdots A$ & D-H & $\mathrm{H} \cdots \mathrm{A}$ & $\mathrm{D} \cdots \mathrm{A}$ & angle \\
\hline $\mathrm{N} 3-\mathrm{H} 17 \cdots \mathrm{O} 3^{\mathrm{i}}$ & $0.88(2)$ & $2.34(2)$ & $3.1779(19)$ & $159.2(18)$ & $\mathrm{N} 2-\mathrm{H} 12 \cdots \mathrm{O} 2$ vii & $0.89(6)$ & $2.34(6)$ & $3.206(6)$ & $165(5)$ \\
\hline $\mathrm{O} 2-\mathrm{H} 2 \cdots \mathrm{O} 7 \mathrm{vi}$ & 0.84 & 2.03 & $2.8420(18)$ & 163 & $\mathrm{O} 2-\mathrm{H} 2 \cdots \mathrm{O} 5{ }^{\mathrm{ii}}$ & 0.82 & 2.11 & $2.922(8)$ & 171 \\
\hline $\mathrm{O} 3-\mathrm{H} 27 \cdots \mathrm{O} 6$ & 0.84 & 1.95 & $2.784(2)$ & 174 & $\mathrm{O} 3-\mathrm{H} 27 \cdots \mathrm{O} 8$ viii & $0.71(5)$ & $2.18(5)$ & $2.861(8)$ & $163(6)$ \\
\hline $\mathrm{O} 3-\mathrm{H} 27 \cdots \mathrm{O} 7$ & 0.84 & 2.674 & $3.248(2)$ & 126.79 & $\mathrm{O} 2-\mathrm{H} 2 \cdots \mathrm{O} 8$ & 0.821 & 2.658 & $3.272(9)$ & 132.9 \\
\hline
\end{tabular}

Symmetry codes: ${ }^{\mathrm{i}} 1-\mathrm{x}, 1-\mathrm{y}, 1-\mathrm{z} ;{ }^{\mathrm{ii}} 1+\mathrm{x}, \mathrm{y}, \mathrm{z} ;{ }^{\text {iii }}-1-\mathrm{x}, 1-\mathrm{y},-\mathrm{z} ;{ }^{\text {iv }} 2-\mathrm{x}, 2-\mathrm{y}, 1-\mathrm{z}^{\mathrm{v}} 1+\mathrm{x}, 1+\mathrm{y}, \mathrm{z} ;{ }^{\mathrm{vi}}-\mathrm{x}, 1-\mathrm{y},-\mathrm{z} ;{ }^{\text {vii }} 1-\mathrm{x}, 1-\mathrm{y}$, $2-\mathrm{z}_{\text {; }}^{\text {viii }}-1-\mathrm{x}, 1-\mathrm{y}, 1-\mathrm{z}$.

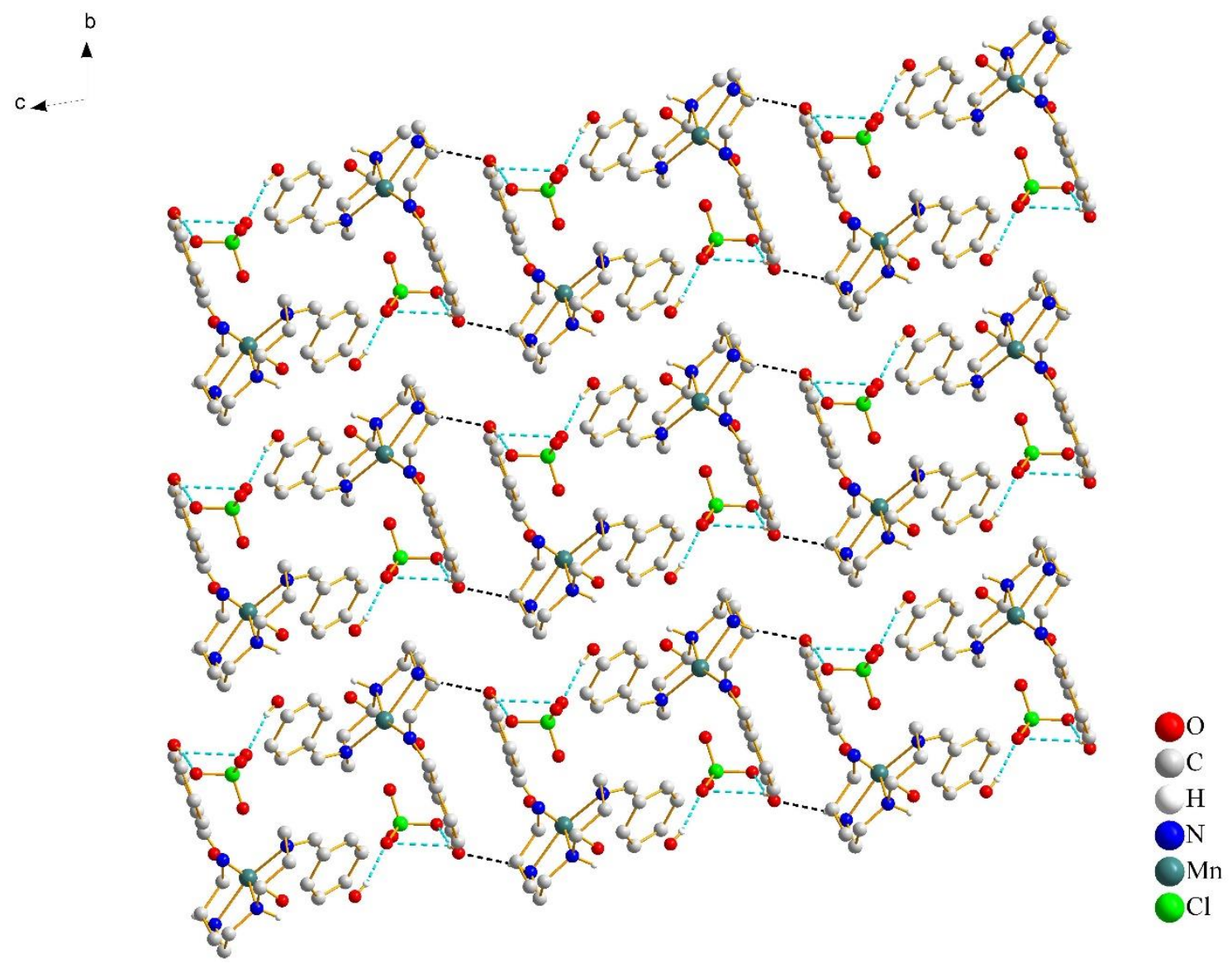

Figure 5. Crystal packing of complex 2 at $100 \mathrm{~K}$, viewed along the $a$-axis. The cation-anion O-H...O hydrogen bonds are shown with cyan blue dash lines and the cation-cation $\mathrm{N}-\mathrm{H}$... O hydrogen bonds are shown with black lines. Most of the hydrogen atoms were omitted for clarity, except for those involved in hydrogen bonds.

\subsection{Hirshfeld Surface Analysis}

To gain deeper insight into the supramolecular contacts in $\mathbf{1}$ and $\mathbf{2}$, we undertook Hirshfeld surface analysis using CrystalExplorer 17.5. The Hirshfeld surfaces for the cations of complexes 1 and $\mathbf{2}$ were mapped with the $d_{\text {norm }}$ function $[39,40]$, which shows several 
red spots. For 1, the four strongest red spots were due to $\mathrm{N}-\mathrm{H} \cdots \mathrm{O}$ and $\mathrm{O}-\mathrm{H} \cdots \mathrm{O}$ hydrogen bonding interactions, and the weak red spots were due to $\mathrm{C}-\mathrm{H} \cdots \mathrm{O}$ interactions (Figure $6 a)$. The hydrogen bond was one of the major interactions here, contributing to $17 \%$ of all interactions in Figure 6c.

a)
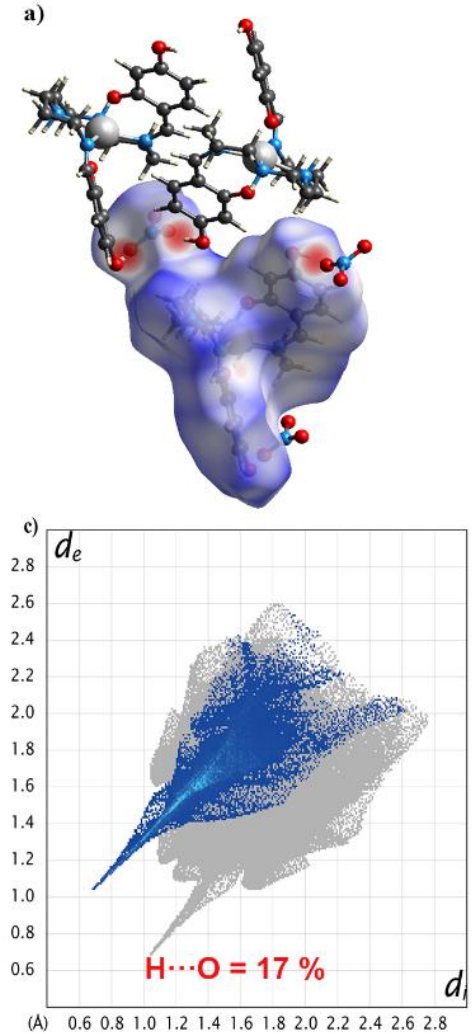
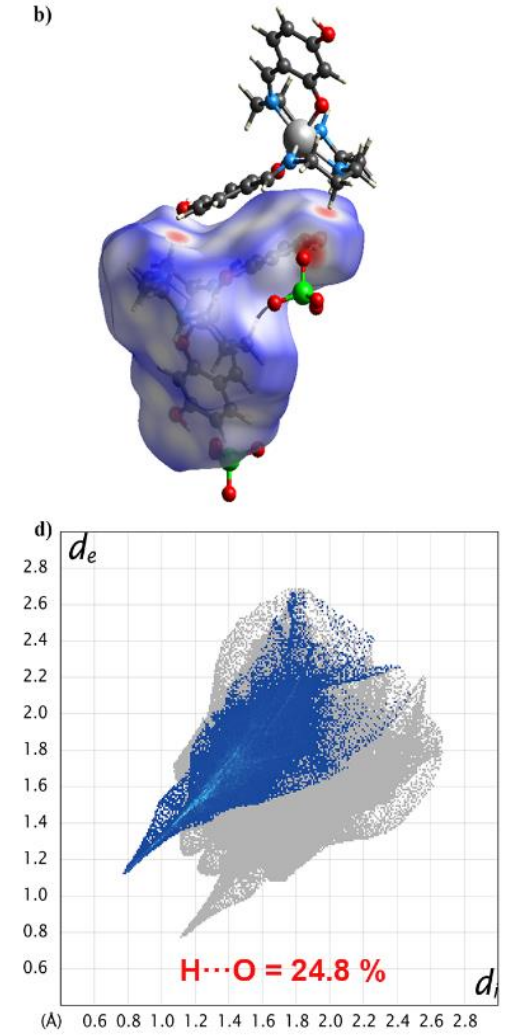

Figure 6. The $\mathrm{N}-\mathrm{H} \cdots \mathrm{O}$ and $\mathrm{O}-\mathrm{H} \cdots \mathrm{O}$ hydrogen bonding interactions in $1(\mathbf{a})$ and 2 (b) through Hirshfeld surface mapping by $\mathrm{d}_{\text {norm }}$ function. $2 \mathrm{D}$ fingerprint plots of all contacts: $\mathrm{H} \cdots \mathrm{O}$ for 1 (c) and 2 (d) at $298 \mathrm{~K}$.

For complex 2, owing to the change in anions, the hydrogen bond contributed to $24.8 \%$ of all interactions (Figure $6 \mathrm{~d}$ ). This supports the discussion above and suggests that the $\mathrm{OH}$ group in the (4-OH-sal-N-1,5,8,12) ${ }^{2-}$ ligand is critical in linking the [Mn $(4-\mathrm{OH}-\mathrm{sal}-\mathrm{N}-$ $1,5,8,12)]^{+}$cations together in these structures.

In order to more intuitively study the influence of hydroxyl on the hydrogen bond interaction, we introduced Hirshfeld surface analysis on the complex $\left[\mathrm{Mn}\left(4-\mathrm{OC}_{6} \mathrm{H}_{13^{-}}\right.\right.$ sal-N-1,5,8,12)] $\mathrm{NO}_{3} \cdot \mathrm{H}_{2} \mathrm{O}$ [16] (Figure 7). Though it crystallizes as an $\mathrm{H}_{2} \mathrm{O}$ solvate, the hydrogen bond contributed to only $9.6 \%$ of all interactions. All in all, the $\mathrm{OH}$ group played a significant role in non-covalent interactions.

From the Hirshfeld analysis, it was very clear that the hydroxyl group effectively enhanced the hydrogen bonding interactions in both complexes. However, these noncovalent intermolecular forces were insufficient to result in a cooperative SCO. The cation structures were tightly packed, hindering the distortion required to undergo SCO. 
a)

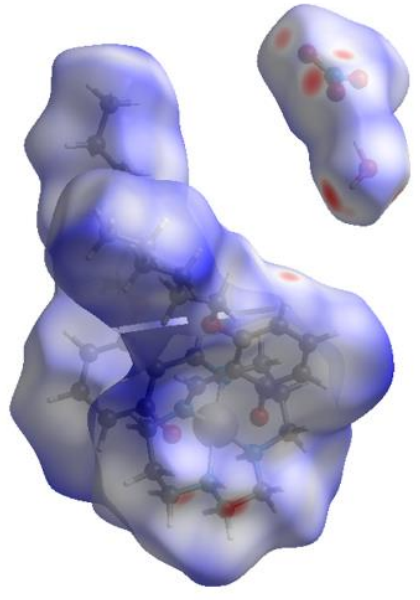

b)

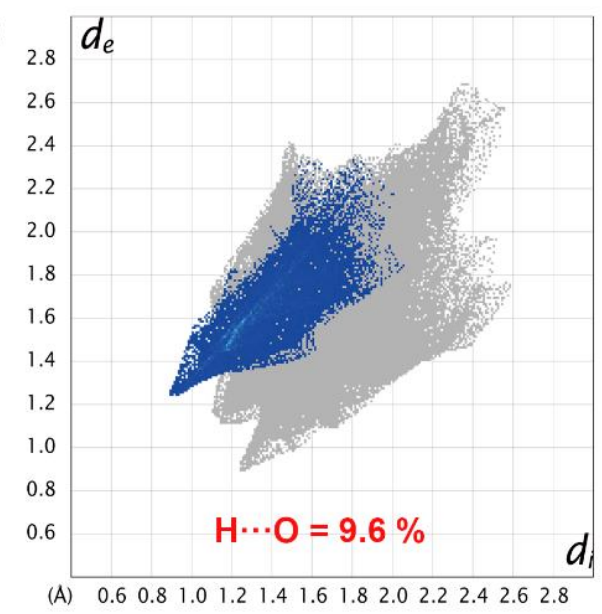

Figure 7. Hirshfeld surface mapped with $\mathrm{d}_{\text {norm }}(\mathbf{a}) ; 2 \mathrm{D}$ fingerprint plots of $\mathrm{H} \cdots \mathrm{O}$ for $\left[\mathrm{Mn}\left(4-\mathrm{OC}_{6} \mathrm{H}_{13^{-}}\right.\right.$ sal- $\mathrm{N}-1,5,8,12)] \mathrm{NO}_{3} \cdot \mathrm{H}_{2} \mathrm{O}(\mathbf{b})$.

\subsection{Magnetic Characterization}

The temperature dependence of the product $\chi_{M} T\left(\chi_{M}\right.$ is the molar paramagnetic susceptibility) versus $T$ plots for the crystalline samples of complexes $\mathbf{1}$ and $\mathbf{2}$ is shown in Figures 8 and 9 , respectively.

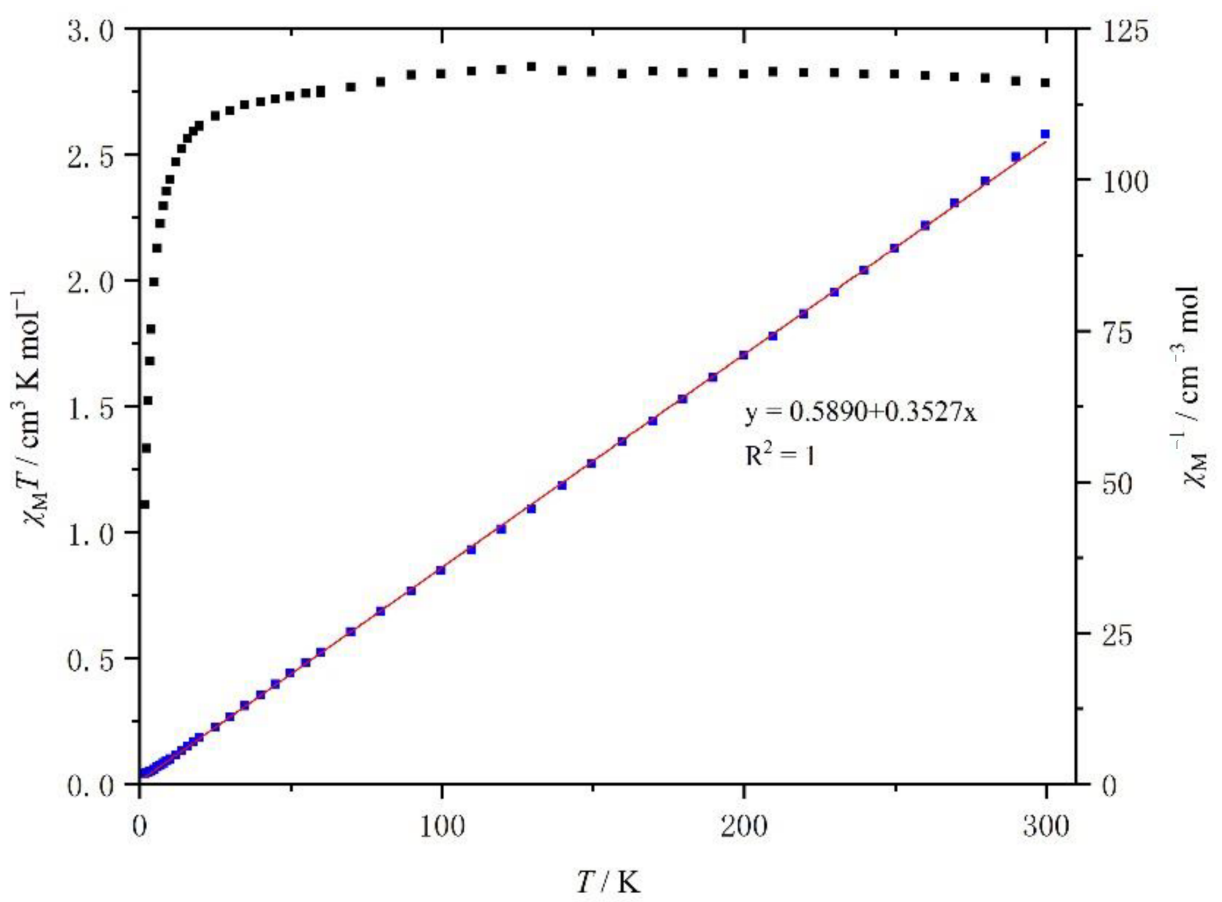

Figure 8. Temperature dependence of the $\chi_{\mathrm{M}} T$ of $[\mathrm{Mn}(4-\mathrm{OH}-\mathrm{sal}-\mathrm{N}-1,5,8,12)] \mathrm{NO}_{3}$ between 2 and $300 \mathrm{~K}$. 


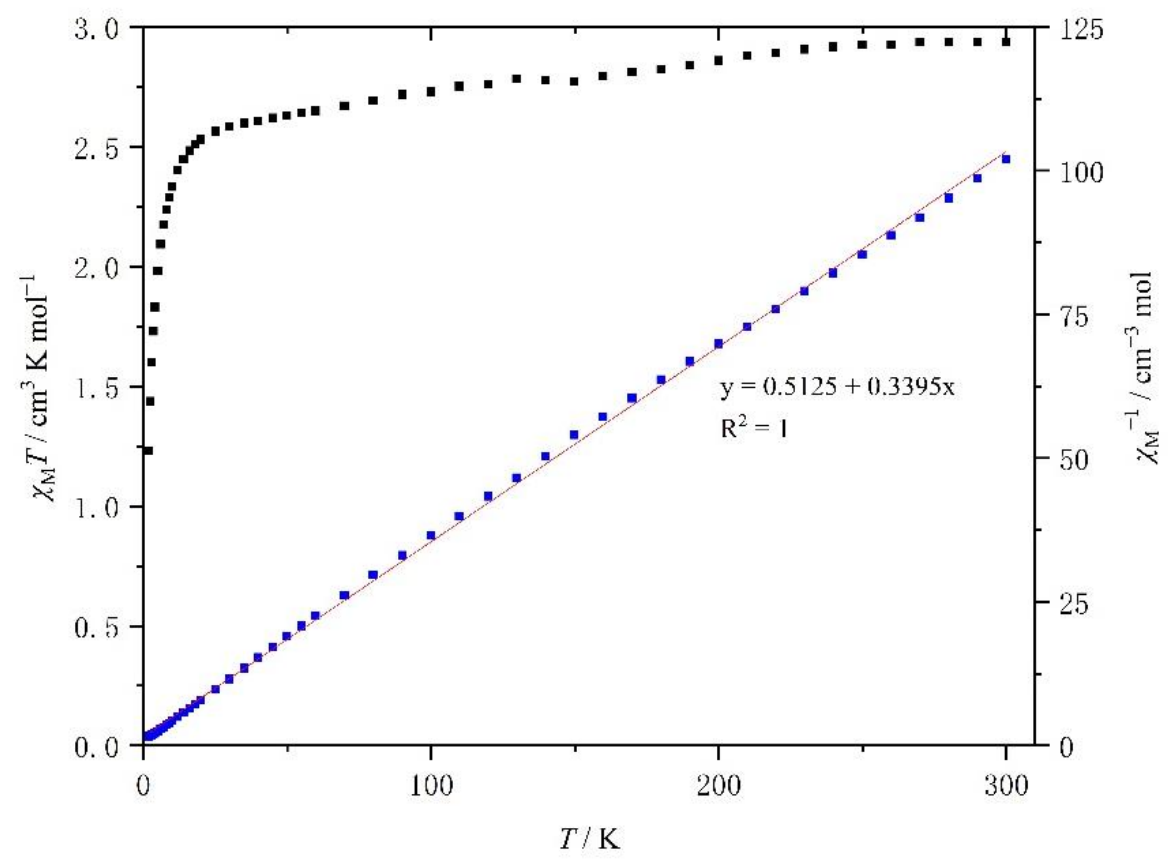

Figure 9. Temperature dependence of the $\chi_{\mathrm{M}} T$ of $[\mathrm{Mn}(4-\mathrm{OH}-\mathrm{sal}-\mathrm{N}-1,5,8,12)] \mathrm{ClO}_{4}$ between 2 and $300 \mathrm{~K}$.

At room temperature, the $\chi_{\mathrm{M}} T$ value of 1 was about $2.79 \mathrm{~cm}^{3} \mathrm{~K} \mathrm{~mol}^{-1}$, which is typical of an $\mathrm{HS} \mathrm{Mn}{ }^{3+}$ center $(S=2)$ with a $g$ value of 2.0 (Figure 7$)$. As the temperature went down, the $\chi_{\mathrm{M}} T$ value was constant until $20 \mathrm{~K}$, when it decreased rapidly because of the ZFS (zero field split) effects of $\mathrm{HS} \mathrm{Mn}{ }^{3+}$ ions. However, within the temperature range, the $\chi_{\mathrm{M}}^{\mathrm{T}}$ value did not drop to $1.0 \mathrm{~cm}^{3} \mathrm{~K} \mathrm{~mol}^{-1}$. The temperature dependence of the $\chi_{\mathrm{M}}{ }^{-1}$ of complex 1 is shown in Figure 7. It is linear between 2 and $300 \mathrm{~K}$ and a linear least-squares fit yields a Curie constant of $2.84 \mathrm{emu} \mathrm{K} \mathrm{mol}^{-1}$, a Weiss temperature $\theta$ of $-1.67 \mathrm{~K}$, while the Curie constant and $\theta$ value of compound 2 was $2.95 \mathrm{emu} \mathrm{K} \mathrm{mol}^{-1}$ and $-1.51 \mathrm{~K}$ (Figure 8).

The magnetic characterization of $[\mathrm{Mn}(4-\mathrm{OH}-\mathrm{sal}-\mathrm{N}-1,5,8,12)] \mathrm{ClO}_{4}$ was similar to that of complex 1, and increasing the size of the anion from $\mathrm{NO}_{3}{ }^{-}$from $\mathrm{ClO}_{4}{ }^{-}$seems to have had no effect on the magnetic behavior.

\section{Conclusions}

In an effort to synthesize new $\mathrm{Mn}$ (III) SCO complexes, we have described two new isomorphic [Mn(4-OH-sal-N-1,5,8,12)]Y $\left(\mathrm{Y}=\mathrm{NO}_{3}{ }^{-}\right.$and $\left.\mathrm{ClO}_{4}{ }^{-}\right)$complexes. The crystal structure of these compounds is rich in non-covalent contacts (hydrogen bonding and $\pi \cdots \pi$ interactions) between the mononuclear cations and anions. Whereas, compared with other $\mathrm{Mn}(\mathrm{III})$ hexadentate Schiff base SCO complexes, such as [Mn(5-OMe-sal-N-1,5,8,12)]Cl and $\left[\mathrm{Mn}\left(\right.\right.$ sal-N-1,5,8,12) $\mathrm{NO}_{3}$, the introduction of hydroxyl groups makes the $\mathrm{Mn}(\mathrm{III})$ cations dimerized and weakens the interactions between anions and cations. Besides, the Mn $\cdots \mathrm{Mn}$ separations are short and the connections between $\mathrm{Mn}^{3+}$ centers are extremely close. They may limit the $\mathrm{Mn}^{3+}$ cations to change their coordination geometry.

Author Contributions: Methodology, Z.-M.Y.; formal analysis, Y.-T.W. and P.-Y.X.; investigation, Y.-T.W. and P.-Y.X.; resources, Y.-H.L.; project administration, S.W.; All authors have read and agreed to the published version of the manuscript.

Funding: This research received no external funding.

Data Availability Statement: The data presented in this study are available in this article.

Acknowledgments: We gratefully acknowledge financial support from the Natural Science Foundations of China (grant no. 21771110) and from the Priority Academic Program Development (PAPD) of Jiangsu Higher Education Institutions (grant no. YX03002). 
Conflicts of Interest: There is no conflict to declare.

\section{References}

1. Vogelsberg, C.S.; Garcia-Garibay, M.A. Crystalline molecular machines: Function, phase order, dimensionality, and composition. Chem. Soc. Rev. 2012, 41, 1892-1910. [CrossRef] [PubMed]

2. Ohkoshi, S.; Tokoro, H. Photomagnetism in Cyano-Bridged Bimetal Assemblies. Acc. Chem. Res. 2012, 45, 1749-1758. [CrossRef] [PubMed]

3. Koumousi, E.S.; Jeon, I.-R.; Gao, Q.; Dechambenoit, P.; Woodruff, D.N.; Merzeau, P.; Buisson, L.; Jia, X.; Lionel, B.; Volatron, F.; et al. Metal-to-Metal Electron Transfer in Co/Fe Prussian Blue Molecular Analogues: The Ultimate Miniaturization. J. Am. Chem. Soc. 2014, 136, 15461-15464. [CrossRef] [PubMed]

4. Irie, M.; Fukaminato, T.; Matsuda, K.; Kobatake, S. Photochromism of Diarylethene Molecules and Crystals: Memories, Switches, and Actuators. Chem. Rev. 2014, 114, 12174-12277. [CrossRef] [PubMed]

5. Zhang, J.L.; Zhong, J.-Q.; Lin, J.D.; Hu, W.P.; Wu, K.; Xu, G.Q.; Wee, A.T.S.; Chen, W. Towards single molecule switches. Chem. Soc. Rev. 2015, 44, 2998-3022. [CrossRef] [PubMed]

6. Gerhard, L.; Edelmann, K.; Homberg, J.; Valasek, M.; Bahoosh, S.G.; Lukas, M.; Pauly, F.; Mayor, M.; Wulfhekel, W. An electronically actuated molecular toggle switch. Nat. Commun. 2017, 8, 14672. [CrossRef]

7. Kahn, O.; Martinez, C.J. Spin-transition Polymers: From Molecular Materials Toward Memory Devices. Science 1998, 279 , 44-48. [CrossRef]

8. Southon, P.D.; Liu, L.; Fellows, E.A.; Price, D.J.; Halder, G.J.; Chapman, K.W.; Moubaraki, B.; Murray, K.S.; Létard, J.-F.; Kepert, C.J. Dynamic Interplay between Spin-Crossover and Host-Guest Function in a Nanoporous Metal-Organic Framework Material. J. Am. Chem. Soc. 2009, 131, 10998-11009. [CrossRef]

9. Bousseksou, A.; Molnár, G.; Salmon, L.; Nicolazzi, W. Molecular spin crossover phenomenon: Recent achievements and prospects. Chem. Soc. Rev. 2011, 40, 3313-3335. [CrossRef]

10. Linares, J.; Codjovi, E.; Garcia, Y. Pressure and Temperature Spin Crossover Sensors with Optical Detection. Sensors 2012, 12, 4479-4492. [CrossRef]

11. Gao, D.; Liu, Y.; Miao, B.; Wei, C.; Ma, J.-G.; Cheng, P.; Yang, G.-M. Pressure Sensor with a Color Change at Room Temperature Based on Spin-Crossover Behavior. Inorg. Chem. 2018, 57, 12475-12479. [CrossRef] [PubMed]

12. Sim, P.G.; Sinn, E. First manganese(III) spin crossover and first d4 crossover: Comment on cytochrome-oxidase. J. Am. Chem. Soc. 1981, 103, 241-243. [CrossRef]

13. Morgan, G.G.; Murnaghan, K.D.; Müller-Bunz, H.; McKee, V.; Harding, C.J. A Manganese(III) Complex That Exhibits Spin Crossover Triggered by Geometric Tuning. Angew. Chem. Int. Ed. 2006, 45, 7192-7195. [CrossRef] [PubMed]

14. Ossinger, S.; Naggert, H.; Kipgen, L.; Jasper-Toennies, T.; Rai, A.; Rudnik, J.; Nickel, F.; Arruda, L.M.; Bernien, M.; Kuch, W.; et al. Vacuum-Evaporable Spin-Crossover Complexes in Direct Contact with a Solid Surface: Bismuth versus Gold. J. Phys. Chem. C 2017, 121, 1210-1219. [CrossRef]

15. Wang, S.; Ferbinteanu, M.; Marinescu, C.; Dobrinescu, A.; Ling, Q.-D.; Huang, W. Case Study on a Rare Effect: The Experimental and Theoretical Analysis of a Manganese(III) Spin-Crossover System. Inorg. Chem. 2010, 49, 9839-9851. [CrossRef] [PubMed]

16. Gandolfi, C.; Cotting, T.; Martinho, P.N.; Sereda, O.; Neels, A.; Morgan, G.G.; Albrecht, M. Synthesis and self-assembly of spin-labile and redox-active manganese(iii) complexes. Dalton Trans. 2010, 40, 1855-1865. [CrossRef] [PubMed]

17. Martinho, P.N.; Gildea, B.; Harris, M.M.; Lemma, T.; Naik, A.D.; Müller-Bunz, H.; Keyes, T.E.; Garcia, Y.; Morgan, G.G. Cooperative Spin Transition in a Mononuclear Manganese(III) Complex. Angew. Chem. Int. Ed. 2012, 51, 12597-12601. [CrossRef]

18. Gildea, B.; Gavin, L.C.; Murray, C.A.; Müller-Bunz, H.; Harding, C.J.; Morgan, G.G. Supramolecular modulation of spin crossover profile in manganese(III). Supramol. Chem. 2012, 24, 641-653. [CrossRef]

19. Pandurangan, K.; Gildea, B.; Murray, C.; Harding, C.J.; Müller-Bunz, H.; Morgan, G.G. Lattice Effects on the Spin-Crossover Profile of a Mononuclear Manganese(III) Cation. Chem. A Eur. J. 2012, 18, 2021-2029. [CrossRef]

20. Wang, S.; He, W.-R.; Ferbinteanu, M.; Li, Y.-H.; Huang, W. Tetragonally compressed high-spin Mn(III) Schiff base complex: Synthesis, crystal structure, magnetic properties and theoretical calculations. Polyhedron 2013, 52, 1199-1205. [CrossRef]

21. Chen, Y.; Gao, F.; Wei, R.-M.; Zhang, Y.; Zhang, Y.-Q.; Song, Y. Spin-crossover phenomena of the mononuclear MnIII complex tuned by metal dithiolene counteranions. Dalton Trans. 2014, 43, 3783-3791. [CrossRef] [PubMed]

22. Gildea, B.; Harris, M.M.; Gavin, L.C.; Murray, C.A.; Ortin, Y.; Müller-Bunz, H.; Harding, C.J.; Lan, Y.; Powell, A.K.; Morgan, G.G. Substituent Effects on Spin State in a Series of Mononuclear Manganese(III) Complexes with Hexadentate Schiff-Base Ligands. Inorg. Chem. 2014, 53, 6022-6033. [CrossRef] [PubMed]

23. Morgan, G.G.; Fitzpatrick, A.J.; Trzop, E.; Müller-Bunz, H.; Dîrtu, M.M.; Garcia, Y.; Collet, E. Electronic vs. structural ordering in a manganese(III) spin crossover complex. Chem. Commun. 2015, 51, 17540-17543.

24. Wang, S.; Li, Y.-H.; Huang, W. Effects of Big Planar Anions on the Spin Transition of a Mononuclear Manganese(III) Complex with a Hexadentate Schiff-Base Ligand. Eur. J. Inorg. Chem. 2015, 2015, 2237-2244. [CrossRef]

25. Wang, S.; Xu, W.-T.; He, W.-R.; Takaishi, S.; Li, Y.-H.; Yamashita, M.; Huang, W. Structural insights into the counterion effects on the manganese(iii) spin crossover system with hexadentate Schiff-base ligands. Dalton Trans. 2016, 45, 5676-5688. [CrossRef]

26. Wang, S.; Li, Y.-J.; Ju, F.-F.; Xu, W.-T.; Kagesawa, K.; Li, Y.-H.; Yamashita, M.; Huang, W. The molecular and supramolecular aspects in mononuclear manganese(iii) Schiff-base spin crossover complexes. Dalton Trans. 2017, 46, 11063-11077. [CrossRef] 
27. Barker, A.; Kelly, C.T.; Kühne, I.A.; Hill, S.; Krzystek, J.; Wix, P.; Esien, K.; Felton, S.; Müller-Bunza, H.; Morgan, G.G. Spin state solvomorphism in a series of rare $S=1$ manganese(III) complexes. Dalton Trans. 2019, 48, 15560-15566. [CrossRef] [PubMed]

28. Kazakova, A.V.; Tiunova, A.V.; Korchagin, D.V.; Shilov, G.V.; Yagubskii, E.B.; Zverev, V.N.; Yang, S.C.; Lin, J.; Lee, J.; Maximova, O.V.; et al. The First Conducting Spin-Crossover Compound Combining a Mn III Cation Complex with Electroactive TCNQ Demonstrating an Abrupt Spin Transition with a Hysteresis of 50 K. Chem. A Eur. J. 2019, 25, 10204-10213. [CrossRef]

29. Zhao, S.-Z.; Qin, C.-Y.; Wang, S.; Yamashita, M.; Li, Y.-H.; Huang, W. Structure function correlations in mononuclear manganese(III) spin crossover systems with a big conjugated hexadentate Schiff-base ligand. Dalton Trans. 2020, 49, 4293-4305. [CrossRef]

30. Villaman, D.; McMonagle, C.J.; Probert, M.R.; Peña, O.; Moreno, Y.; Fuentealba, M. Structural studies of a manganese(iii) complex with spin-crossover and thermochromic properties. CrystEngComm 2020, 22, 3221-3233. [CrossRef]

31. Krüger, C.; Augustín, P.; Dlháň, L.; Pavlik, J.; Moncol', J.; Nemec, I.; Boča, R.; Renz, F. Iron(III) complexes with pentadentate Schiff-base ligands: Influence of crystal packing change and pseudohalido coligand variations on spin crossover. Polyhedron 2015, 87, 194-201. [CrossRef]

32. Yamada, M.; Hagiwara, H.; Torigoe, H.; Matsumoto, N.; Kojima, M.; Dahan, F.; Tuchagues, J.P.; Re, N.; Iijima, S. A variety of spin-crossover behaviors depending on the counter anion: Two-dimensional complexes constructed by $\mathrm{NH} \mathrm{Cl}$ hydrogen bonds, [FeIIH3LMe]Cl·X (X=PF6, AsF6, SbF6, CF3SO3; H3LMe=Tris[2-\{[(2-methylimidazol-4-yl) methylidene]amino\}ethyl]amine). Chem. Eur. J. 2006, 12, 4536-4549. [CrossRef] [PubMed]

33. Ni, Z.; McDaniel, A.M.; Shores, M.P. Ambient temperature anion-dependent spin state switching observed in "mostly low spin" heteroleptic iron(ii) diimine complexes. Chem. Sci. 2010, 1, 615-621. [CrossRef]

34. Nemec, I.; Herchel, R.; Šalitroš, I.; Trávníček, Z.; Moncol', J.; Fuess, H.; Ruben, M.; Linert, W. Anion driven modulation of magnetic intermolecular interactions and spin crossover properties in an isomorphous series of mononuclear iron(iii) complexes with a hexadentate Schiff base ligand. CrystEngComm 2012, 14, 7015. [CrossRef]

35. Li, B.; Wei, R.-J.; Tao, J.; Huang, R.-B.; Zheng, L.-S.; Zheng, Z. Solvent-Induced Transformation of Single Crystals of a SpinCrossover (SCO) Compound to Single Crystals with Two Distinct SCO Centers. J. Am. Chem. Soc. 2010, 132, 1558-1566. [CrossRef] [PubMed]

36. Wei, R.-J.; Tao, J.; Huang, R.-B.; Zheng, L.-S. Reversible and Irreversible Vapor-Induced Guest Molecule Exchange in SpinCrossover Compounds. Inorg. Chem. 2011, 50, 8553-8564. [CrossRef]

37. Costa, J.S.; Rodríguez-Jiménez, S.; Craig, G.A.; Barth, B.; Beavers, C.M.; Teat, S.J.; Aromí, G. Three-way crystal-tocrystal reversible transformation and controlled spin switching by a nonporous molecular material. J. Am. Chem. Soc. 2014, 136, 3869-3874. [CrossRef]

38. Wannarit, N.; Nassirinia, N.; Amani, S.; Masciocchi, N.; Youngme, S.; Roubeau, O.; Teat, S.J.; Gamez, P. Drastic Effect of Lattice Propionitrile Molecules on the Spin-Transition Temperature of a 2,2'-Dipyridylamino/s-triazine-Based Iron(II) Complex. Inorg. Chem. 2014, 53, 9827-9836. [CrossRef]

39. Spackman, M.A.; Jayatilaka, D. Hirshfeld surface analysis. CrystEngComm. 2009, 11, 19-32. [CrossRef]

40. Hassan, N.H.H.; Abdullah, A.A.; Arshad, S.; Khalib, N.C.; Razak, I.A. Crystal structure and Hirshfeld surface analysis of (E)-3-(2-chloro-6-fluorophenyl)-1-(3-fluoro-4-methoxyphenyl)prop-2-en-1-one. Acta Cryst. Sec. E 2016, 72, 716-719. [CrossRef] 